\title{
Justice Without Favor: Due Process and Separation of Executive and Judicial Powers in State Government
}

Separation of powers is a necessary "bulwark against tyranny"1 in part because allowing one branch to wield executive and judicial power would impair the impartial administration of the laws. ${ }^{2}$ The Fourteenth Amendment's due process clause ${ }^{3}$ requires states to provide an impartial tribunal for their citizens in criminal prosecutions. Therefore, due process analysis should consider whether a state's institutional structure threatens the impartiality of the criminal tribunal by failing adequately to separate executive and judicial responsibilities. Under the Dreyer doctrine, however, federal courts may not subject a state's separation of powers schemes to due process scrutiny."

This Note challenges that doctrine. It disputes the Court's view that federalism bars due process inquiry into the structure of state government, proposes how courts might determine when a state violates due process by too closely linking the executive and judicial functions, and concludes by illustrating how that proposal might be applied.

1. United States v. Brown, 381 U.S. 437, 443 (1965).

2. See W. Gwyn, The Menning of the Separation of Powers 127 (1965) (one of five primary justifications for separation of powers is to "assure that the laws are impartially administered"); M. Richter, The Political Theory of Montesquieu 84-92 (1977) (guaranteeing impartial judge is one major justification for separation of powers).

3. U.S. CoNST. amend. XIV, § 1. Inadequate separation of legislative and judicial powers, or of legislative and executive powers, in state governments may also pose due process problems. This Note only considers cases of executive-judicial interlock, however, for two reasons. First, the Note's central contention is that courts must replace the Dreyer doctrine with a rule allowing some judicial examination of the due process implications of a state's government structure. Since the federal courts have often applied due process to state court proceedings, especially criminal proceedings, the executivejudicial nexus is the weakest facet of Dreyer. Second, cases of legislative-judicial interlock pose very different problems than cases of executive-judicial interlock. The problems of the former are often akin to those caused by bills of attainder, see infra note 49.

4. Dreyer v. Illinois, 187 U.S. 71,84 (1902). 


\section{Co-Guarantors of an Impartial Tribunal: Separation of Powers and Due Process}

Fourteenth amendment jurisprudence has long considered state practices and procedures that endanger the fundamental right to an impartial judge to violate due process. Classical legal theorists and the framers of the Constitution recognized that inadequate separation of the executive and judicial power posed a significant threat to judicial impartiality. This section proposes, as a synthesis of these two ideas, that courts should consider whether a state system of separation of powers threatens the federal due process right to an impartial judge.

\section{A. Due Process and the Impartial Judge}

The framers of the Fourteenth Amendment emphasized that due process created a right to a "fair" and "impartial trial." That right has long been held to be fundamental to due process, ${ }^{6}$ and the Court has repeatedly held that an impartial judge is an indispensible component of that right. ${ }^{7}$ Indeed, that "neutrality requirement"8 does more than guarantee a particular defendant an unbiased judge. It also forbids procedures that create a "probability that prejudice will result" or the appearance that a judge is

5. See Cong. Grobe, 39th Cong., 1st Sess., 2899 (1866) (Senator Cowan stating due process demands fair trial); Cong. Globe, 42d Cong., 1st Sess., 152-153 (1871) (J. Garfield, participant in 39th Congress, observing Fourteenth Amendment demands impartial trial).

6. See Marshall v. Jerrico, Inc., 446 U.S. 238, 242 (1980) (due process demands impartial tribunal in civil and criminal cases); Adamson v. California, 332 U.S. 46, 53 (1946) (due process creates "right to a fair trial"); Palko v. Connecticut, 302 U.S. 319, 325 (1937) (due process guarantees "fair and enlightened system of justice"); see also R. BERGER, GovERNMENT BY JUDICIARY 193-220 (1977) (due process forbids no more than punishment of anyone by unfair trial); J. ELX, DENOCRACY AND DISTRUST 19 (1980) (function of due process clause is to guarantee fair procedures).

7. See Gerstein v. Pugh, 420 U.S. 103 (1975) (due process demands hearing on probable cause to detain by neutral, detached magistrate); Ward v. Village of Monroeville, 409 U.S. 57, 62 (1972) (due process demands "neutral and detached judge in the first instance"); Coolidge v. New Hampshire, 403 U.S. 443,453 (1971) (due process demands decision to issue search warrant be made by neutral and detached magistrate); Goldberg v. Kelly, 397 U.S. 254, 271 (1970) (impartial decisionmaker "essential" to due process); Chapman v. California, 386 U.S. 18, 23 (1967) (right to impartial judge so basic to due process that courts can never treat its infraction as harmless error); In re Murchison, 349 U.S. 133,136 (1955) (invalidating trial before potentially biased judge because "a fair trial in a fair tribunal is a basic requirement of due process"); Tumey v. Ohio, 273 U.S. 510 (1927) (due process demands impartial judge).

8. Marshall v. Jerrico, Inc., 446 U.S. 238, 242 (1980).

9. Estes v. Texas, 381 U.S. 532, 543 (1965) (due process violated when courtroom proceedings televised, whether or not defendant could show tribunal prejudiced thereby); Turner v. Louisiana, 379 U.S. 466 (1965) (due process violated when key witnesses serve as bailiffs for jury, whether or not actual bias shown); Jackson v. Denno, 378 U.S. 368 (1964) (juries simultaneously deciding admissibility of evidence and guilt of defendant violate due process whether or not defendant can show jury biased thereby). 
biased, ${ }^{10}$ whether or not a specific defendant can show the procedure actually biased the outcome in his particular case. ${ }^{11}$

Like most due process safeguards, the right to an impartial judge assumes special importance in criminal cases. The liberty interest has always received vigorous due process protection. ${ }^{12}$ Furthermore, in an adversarial system in which the government acts as prosecutor, stiff procedural safeguards are necessary to shield the defendant from the state. $^{13}$

\section{B. Separation of Executive and Judicial Powers: Guarantor of an Im- partial Judge}

Classical political theorists recognized that government structures that do not sufficiently separate executive and judicial powers create a high probability that the judge in a criminal suit will be biased. The executive, as the branch accusing the defendant, naturally desires to convict him. When the accusing branch can control or influence the judge, the judge's ability to objectively weigh the prosecution's case is endangered. ${ }^{14}$ The

10. Taylor v. Hayes, 418 U.S. 488, 501 (1974) (appearance of impartiality requirement prohibits trial before judge who previously held defendant in contempt); Marberry v. Pennsylvania, 400 U.S. 455 (1971) (same); In re Murchison, 349 U.S. 133, 136 (1955) (justice must satisfy the appearance of justice).

11. In re Murchison, 349 U.S. 133 (1955) (judge hearing own contempt charges violates due process whether or not actual bias shown). See also Marshall v. Jerrico, Inc., 446 U.S. 238, 242 (1980) (neutrality requirement may bar trial before judge who has no actual bias); Connally v. Georgia, 429 U.S. 245 (1977) (prohibiting paying justice of peace only when he or she issued search warrant, whether or not actual bias shown); Ward v. Village of Monroeville, 409 U.S. 57 (1972) (prohibiting judge with pecuniary interest in fines collected by court from serving as judge, whether or not defendant can show actual bias); Tumey v. Ohio, 273 U.S. 510 (1927) (same).

12. See Lassiter v. Department of Social Services, 452 U.S. 18, 25-27 (1981) (defendant's right to counsel tied to risk trial poses to his or her personal freedom); Scott v. Illinois, 440 U.S. 367,373 (1979) (trials leading to loss of liberty different in kind and meriting greater due process safeguards than trials resulting in fines or threat of imprisonment); Arnett v. Kennedy, 416 U.S. 134, 157 (1974) (right to continued employment merits lesser protection than "elemental freedom from external restraint"); Morrisey v. Brewer, 408 U.S. 471 (1972) (creating higher due process standard for prison parole hearing than for administrative hearing where liberty interest not at stake).

13. See Ross v. Moffitt, 417 U.S. 600, 610 (1974) (since state employs resources at trial to convict defendant, "shield" against state efforts necessary); United States v. Wade, 388 U.S. 218, 223-27 (1967) (adversary system of criminal justice requires that defendant have counsel present at crucial points in criminal prosecution to defend against efforts of law enforcement machinery); McNabb v. United States, 318 U.S. 332, 343 (1943) (society must guard against "overzealous" use of prosecutorial force); see also Frankel, The Search for the Truth: An Umpireal View, 123 U. PA. L. REv. 1031, 1032-40, 1052-59 (1975) (adversary system motivates state prosecutor to place far greater value on obtaining conviction than on discovering truth).

This Note considers only the dangers of executive and judicial interlock in criminal cases, because in most civil cases the executive has only a limited interest in the outcome. Obviously, that is not always the case. See People ex rel. Saranac Land and Timber v. Supreme Court Extraordinary Term, 220 N.Y. 487, 116 N.E. 384 (1917) (Extraordinary Term of New York Supreme Court called by Governor after plaintiff won three suits against state for state lands). The argument advanced here may apply to some civil cases, but this extension presents conceptual problems that go beyond the scope of this Note.

14. See Montesquieu, The Spirit of the Laws 69-71 (T. Nugent trans., J. Pritchard ed., 
classical theorists recognized this threat both when the executive influences the judiciary and when the judiciary controls the executive. ${ }^{16}$

The framers, also, feared these interrelated dangers and sought to avoid them in the Constitution. Their reliance on separation of powers stemmed from their belief that people are inherently self-serving and, therefore, that citizens cannot depend on the virtue of their officials to safeguard individual rights. ${ }^{18}$ The framers sought to create a state that "economizes on virtue"17 by dispersing power within the government, so that the selfish desires of individuals and branches would substitute "opposite and rival interests" for "better motives."18

Separation of judicial and executive powers is, accordingly, crucial. If the judge can be "overpowered, awed or influenced"19 by the executive, he will not provide a "steady, upright and impartial"20 administration of the laws, nor will he check tyrannical or arbitrary prosecutions. ${ }^{21}$ Conversely, if the judge holds "the executive power, the judge might behave with all the violence of an oppressor," and enforce the law with bias. ${ }^{22}$ Therefore, the framers sought to shelter the judiciary from undue executive influence by giving judges life tenure ${ }^{23}$ and guaranteed compensation. ${ }^{24}$

1952) (1st ed. Geneva 1748) (if executive controls judiciary, judge will decide cases on executive's behalf); id. at 36-37 (if executive prosecutes or benefits from confiscation of criminal's property, executive will be biased as judge and executive's ministers will lack requisite "indifference" to serve as judges); J. SADler, The Rights of the KingDOM OR Customs of OUR ANCEstours 87 (1st ed. London 1649) (executive sitting as judge will judge case with bias); J. LILbOURNE, The LAweS Funerall 9 (1st ed. London 1648) (law-executors serving as judges leads to partiality in trials); J. Fortescue, De Laudibus Legum ANGlie, 127-31 (S. Chrimes trans. 1942) (1st ed. n.p., 1467-71) (justice can only be done if judge chosen by king swears to do "justice without favour. . .though the king should command him. . .to the contrary"); $c f$. R. ACHERLEY, THE BRITANNIC ConstituTION 86 (1st ed. London 1727) (if king exercised judicial power in criminal prosecutions he would be judge and party and would enforce the law unfairly).

15. See Montesquieu, supra note 14 , at 70 (judge will use executive power oppressively).

16. See J. Adams, Discourses on Davila, in 6 The Works of John Adams 232-35 (C. Adams ed. 1851) (man's passion for distinction creates ambition, jealousy, vanity); The FEDERALIST No. 10, (J. Madison) (man motivated by dictates of personal interest); id. No. 15 (A. Hamilton) (in state of nature, man's actions do not conform to dictates of justice); T. JeFrerson, Notes On The State of Virginia, in 4 The Works of Thomas Jefrerson 21 (P. Ford ed. 1904) ("Mankind soon learns to make interested uses of every right and power which they possess, or may assume.").

17. Ackerman, The Storrs Lectures: Discovering the Constitution, 93 YALE L.J. 1013, 1013 (1984).

18. The Federalist No. 51, at 322 (J. Madison) (C. Rossiter ed. 1967); see also J. Adams, Letter to Richard Henry Lee, 15 November 1775, in 4 J. ADAMs, supra note 16 at 186 (constitu* tional separation of powers necessary to check human nature's tendency toward tyranny); A. HAMILTON, Tully Essays, in 6 The Works of Alexander Hamilton 418 (H. Lodge ed. 1904) (constitution necessary to prevent demagogues using factions to gain power).

19. The Federalist No. 78, at 466 (A. Hamilton) (C. Rossiter ed. 1967).

20. Id. at 465 .

21. Id. No. 47, at 303 (J. Madison) (C. Rossiter ed. 1967) (quoting Montesquieu); see also

DEClaration of INDEPENDENCE (criticizing king for controlling judicial salary and tenure).

22. The Federalist No. 47, at 303 (J. Madison) (C. Rossiter ed. 1967) (quoting Montesquieu) (emphasis omitted).

23. U.S. CoNST. art. III, § 1.

24. U.S. ConsT. art. III, \& 1 . 
The framers also believed, however, that complete separation of powers is undesirable. An interlocking of the branches is necessary, so that the branches, without having control over the acts of each other, ${ }^{25}$ can "by their mutual relations be the means of keeping each other in their proper places." ${ }^{26}$ Furthermore, while the framers emphasized the dangers of too closely linking executive and judicial functions, they also acknowledged that the article III safeguards are not the only means to preserve judicial independence. ${ }^{27}$ The Federalist cited with approval state systems in which judges held office for limited terms, ${ }^{28}$ were selected by the legislature, ${ }^{29}$ or were nominated by the executive and confirmed by an elected governor's council..$^{30}$ To the framers, the critical question was whether a particular method of arranging a government created a system in which the branches checked each other, or whether it compromised the independence of a particular branch, thereby endangering the impartial administration of the law.

\section{Separation of Powers as a Requirement of Due Process}

The Supreme Court has often invalidated state government structures that endanger the due process rights to a fair trial and an impartial judge. Accordingly, state jury procedures, systems for paying judges, and for granting search warrants have been struck down, even though they were not shown to have caused any specific injustice. ${ }^{31}$ Since systems that link judicial and executive powers threaten the impartiality of the judicial tribunal, the Fourteenth Amendment ought to require courts to consider whether a given state structure separates the two powers sufficiently to safeguard the individual's right to an impartial judge. The Supreme Court, however, not only refuses to decide what constitutes "sufficient" separation, but holds that federalism concerns preclude judicial inquiry into state separation of powers schemes.

25. The Federalist No. 47, at 302 (J. Madison) (C. Rossiter ed. 1967).

26. Id. No. 51, at 320 (J.Madison).

27. See id. No. 47, at 301-02 (J. Madison) (Britain as example of separation of powers).

28. Id. at 307 (discussing Delaware and Pennsylvania constitutions); see DeL. ConsT. of 1776, art. 17 (one-year term for "executive magistrate" sitting on highest court); PA. CoNST. of 1776, § 23 (seven-year terms for supreme Court judges); $c f$. MONTEsquieu, supra note 14, at 71 (espousing short judicial terms).

29. The Federalist No. 47, at 306 (J. Madison) (C. Rossiter ed. 1967) (Delaware const.).

30. Id. at 306 (Pennsylvania const.).

31. See Connally v. Georgia, 429 U.S. 245 (1977) (paying justice of peace only if he issues search warrants violates due process); Coolidge v. New Hampshire, 403 U.S. 443 (1971) (state attorney general issuing search warrants violates due process); Turner v. Louisiana, 379 U.S. 466 (1965) (prosecution witnesses may not serve as bailiffs having charge of jury); Jackson v. Denno, 378 U.S. 368 (1964) (jury may not decide both admissibility and weight of confession); Tumey v. Ohio, 273 U.S. 510 (1927) (due process violated when judge receives portion of fines administered by his court). 


\section{Federalism and Due Process Scrutiny of State SEParation OF POWERS}

The Supreme Gourt has held that federalism bars due process scrutiny into state separation of executive and judicial powers. This section argues that federalism places limitations on that inquiry, but does not foreclose it.

\section{A. The Dreyer Doctrine}

The Supreme Court first held that due process did not impose separation of powers requirements upon the states in Dreyer $v$. Illinois. ${ }^{32}$ In Dreyer, a prisoner argued that his due process rights were violated when the Illinois State Board of Pardons, a part of the executive branch, made the "judicial" decision that he did not qualify for release from prison. In denying this claim, the Court declared that a state's determination of whether its "legislative, executive and judicial powers . . . shall be kept altogether distinct and separate . . . cannot be an element in the inquiry whether the due process of law prescribed by the Fourteenth Amendment has been respected by the State or its representatives."

The Court has not applied the doctrine to another case of an allegedly inadequate separation of executive and judicial powers in a state criminal system, ${ }^{34}$ but, in dicta, has repeatedly restated the Dreyer doctrine. ${ }^{35}$ Most recently, the Court flatly observed: "[T] ers embodied in the Federal Constitution is not mandatory on the States."

The doctrine has had a dramatic impact in state and lower federal courts. Dreyer has long been read as establishing that "separation of power principles do not apply to the States," ${ }^{\text {"37 }}$ and conclusory references

32. 187 U.S. 71 (1902).

33. Id. at 84 .

34. The Supreme Court has commonly invoked doctrine to uphold state statutes delegating legislative functions to judiciary. See Minnesota v. Clover Leaf Creamery Co., 449 U.S. 456, 461 n.6 (1981) (state policy may be enunciated by courts and legislatures); Teamsters Union v. Hanke, 339 U.S. 470, 479 (1950) (same); Pacific Tel. \& Tel. Co. v. Seattle, 291 U.S. 300, 303-04 (1934) (states may give courts legislative powers); O’Donogue v. United States, 289 U.S. 516, 545-46 (1933) (same); Keller v. Potomac Electric Co., 261 U.S. 428, 442-43 (1923) (same); Prentis v. Atlantic Coast Line Co., 211 U.S. 210, 225 (1908) (Virginia's state corporations commission's power to set electric rates and enforce law against violators constitutional because state constitution can unite judicial and legislative functions in single branch).

35. See Mayor of Philadelphia v. Educational Equality League, 415 U.S. 605, 615 n.13 (1974) ("The Constitution does not impose on the States any particular plan for the distribution of governmental powers."); Sweezy v. New Hampshire, 354 U.S. 234, 255 (1957) (noting that plaintiff had not challenged constitutionality of state attorney general serving as investigatory committee of legislature, but observing "the concept of separation of powers embodied in the United States Constitution is not mandatory in state governments."); id. at 256-57 (Frankfurter, J., concurring) ("The Constitution does not impose on the states any particular plan for the distribution of governmental powers.").

36. Whalen v. United States, 445 U.S. 684, 689 n.4 (1979).

37. Caron v. United States, 548 F.2d 366, 367 (1st Gir. 1976); see also Parcell v. Kansas, 468 F. 
to the doctrine have served to refute arguments that the inadequate separation of executive and judicial powers endangers due process. ${ }^{38}$ Accordingly, these courts have rejected (with brief and uncritical restatements of the Dreyer doctrine) allegations that federal due process is violated by state systems that allow the Governor to select a judge to hear a case of the Governor's choosing, ${ }^{39}$ that require the District Attorney's consent before the judge can grant probation, ${ }^{40}$ that give the prosecutor power to determine whether habitual criminals should receive enhanced sentences, ${ }^{41}$ and that confer subpoena power on prosecuting attorneys. ${ }^{42}$

Surprisingly, considering the impact the doctrine has had, the Supreme Court has provided little justification for it. In his concurring opinion in Sweezy $v$. New Hampshire, ${ }^{\text {43 }}$ Justice Frankfurter suggested the only justification for the Dreyer doctrine which any member of the Court has ever advanced. Permitting due process inquiry into state separation of powers arrangements, Frankfurter stated, would "make the deepest inroads upon our federal system."'44 Federalism, then, seems to be the barrier preventing due process inquiry from reaching state separation of powers arrangements.

\section{B. Federalism: How Strong an Objection?}

Frankfurter's terse remark in Sweezy restates his broad view that American federalism consists of two distinct systems, one federal and one state, each with its "proper domain," and "distinctive operations" within its "respective sphere." Frankfurter's or any other theory of federalism

Supp. 1274, 1277 (D. Kan. 1979) ("States are not required to abide by the doctrine of separation of powers."); LaGuardia v. Smith, 288 N.Y. 1, 41 N.E.2d 153, 176 Misc. 482, 485 (1941) ("[T]he Federal authorities have no right to interfere with the States by way of requiring separation of powers as necessary to . . . due process of law.") affd, 288 N.Y. 1, 41 N.E.2d 153 (1942).

38. See Bean v. Nevada, 410 F. Supp. 963,966 (D. Nev. 1974) (state board of pardons, made up of members of judicial and executive branches, not subject to due process challenge as violating separation of powers); State ex rel. Lanier v. Vines, 274 N.C. 486, 494, 164 S.E.2d 161, 165-66 (1968) ("It is for the State to determine whether and to what extent its powers shall be kept separate between the executive, legislative and judicial departments of its government," but relying on N.C Constitution to reduce discretion of commissioner of insurance to fine insurance agenct who violate N.C. law).

39. People v. Davis, 67 Misc. 2d 14, 16, 322 N.Y.S.2d 927, 930-31 (S. Ct., Ontario Co. 1971) (rejecting due process challenge to Extraordinary Term of N.Y. Supreme Court).

40. Chromiak v. Field, 406 F.2d 502, 504-05 (9th Cir. 1969) (California penal code provision upheld), cert. denied, 396 U.S. 1017 (1970).

41. Martin v. Parratt, 412 F. Supp. 544, 548-49 (D. Neb. 1976) (upholding Nebraska habitual criminal statute allowing prosecutors to seek mandatory enhanced sentences for habitual criminals), aff'd, 549 F.2d 50 (8th Cir. 1977).

42. Pollard v. Roberts, 283 F. Supp. 248, 255 (E.D. Ark. 1969) (Ark. statute not prima facie unconstitutional), aff'd per curiam, 393 U.S. 14 (1968).

43. 354 U.S. 234,255 (1956).

44. Id. at 256.

45. Knapp v. Schweitzer, 357 U.S. 371, 375 (1958).

46. Feldman v. United States, 322 U.S. 487,490 (1944). 
should not, however, bar due process inquiry into a state's system of separation of powers if that system threatens the federal right to an impartial judge.

A state's decision to structure its government a certain way has never been a "sacred province of state autonomy" 4 into which the federal courts could not pry. The ability of a state to structure its government has always been subject to federal constraints when the structure has endangered the right to an impartial tribunal. ${ }^{48}$ At a minimum, for example, article I, section 10's ban on state bills of attainder and ex post facto laws seeks to guarantee an impartial tribunal by preventing an unfair "trial by legislature" during periods when the legislature is moved by "sudden and strong passions." 99 The Fourteenth Amendment was "an expansion of

47. E.E.O.C. v. Wyoming, 460 U.S. 226, 236 (1983).

48. U.S. CoNST. art. IV $\S 4$ (guarantee clause) may imply some congressional, if not judicial, intervention to separate powers in the states sufficiently to guarantee that states impartially administer justice. Hamilton argued that an impartial judiciary was necessary to preserve "republican" government. The FEderalist No. 78, at 465-72 (A. Hamilton) (C. Rossiter ed). See also Ireland, An Independent Judiciary, in LAw AND AMERICAN HistoRY 428, 430 (S. Presser \& J. Zainaldin eds. 1980). Recently, state courts have read separation of power requirements into the guarantee clause. See Van Sickle v. Shanahan, 212 Kan. 426, 511 P.2d 223 (1973); State v. Lehtola, 55 Wis. 2d 494 (1972). But see In re Interrogatories Propounded by Senate Concerning House Bill 1078, 189 Colo. 1, 536 P.2d 308 (1975) (guarantee clause does not impose separation of powers upon states.

49. Fletcher v. Peck, 10 U.S. (6 Cranch) 87, 138 (1810); see also THE FederalisT No. 44, at 282 (J. Madison) (G. Rossiter ed. 1967) (inadequate separation of legislative and judicial powers poses such danger to "personal security and private rights" that Constitution should impose "additional fences against" bills of attainder). Article I, § 10 may mean more. See United States v. Brown, 381 U.S. 437, 442 (1965) (Article I's ban on federal bills of attainder general safeguard against legislative exercise of judicial function). The Court has not yet read the ban on state bills of attainder in a similar way. However, the broad reading traditionally given art. I, $\S 10$, see Weaver v. Graham, 450 U.S. 24 (1981); Cummings v. Missouri, 71 U.S. 277 (1866); Fletcher v. Peck, 10 U.S. 87, 137 (1810), and parallel language of ban on federal and state bills of attainder suggest that the Court will. In fact, the dissent in Brown expressly argued that a broad reading of $\S 9$ demanded an analogous reading of $\S 10$. See Brown, 381 U.S. at 473 (White, J. dissenting); see also L. TRIBE, AMERICAN Constitutional LAw 491-94 (1978) (bill of attainder clause demands separation of legislative and judicial powers in states); Note, The Bounds of Legislative Specifications, A Suggested Approach to the Bill of Attainder Clause, 72 YALE L.J. 330 (1972) (ban on bills of attainder is implementation of separation of powers). But see Berger, Bills of Attainder: A Study of Amendment by the Court, 63 Cornell. L. REv, 355, 371, 379-82 (1978) (bill of attainder clause not meant to impose separation of powers upon states).

Given that the framers considered separation of powers so important that they used the federal Constitution to require partial separation of state legislative and judicial powers, one might ask why they did not impose similar safeguards regarding the executive and judicial powers. The answer lies in the framers' deference to states' rights. See Berger, supra; ThE FEDERALIST Nos. 35 \& 36 (J. Madison). Federalism concerns were overridden, however, in the special case of bills of attainder because the framers believed that in a republic the legislature was the most powerful branch and therefore that many restraints on its power were necessary, see United States v. Brown, 381 U.S. 437, 442 (1965); The Federalist No. 48, at 344 (J. Madison); Note, supra, at 343-48. Legislativejudicial interlock was therefore more frightening to the framers than executive-judicial interlock. Furthermore, the bill of attainder was the most obvious and easily identifiable form of inadequate separation of powers. No analogous form existed for executive-judicial interlock. This Note contends that the federalism balance has been so radically altered by the Fourteenth Amendment and its subsequent interpretation by the courts, that the framers' deference to states' rights can no longer protect executive-judicial interlock in state governments from due process scrutiny. 
federal power and an intrusion on state sovereignty" which further limited states' freedom in structuring their governments. ${ }^{50}$ In fact, some scholars believe the amendment was adopted to serve precisely that purpose. ${ }^{\text {s1 }}$

Furthermore, the court has, without expressly recognizing it, severely undermined the Dreyer doctrine by using the due process clause to bar egregious mergers of executive and judicial powers in which a single official wears both the executive and judicial hats in a criminal prosecution. Two cases, Tumey $v$. Ohio ${ }^{52}$ and Ward $v$. Village of Monroeville, ${ }^{53}$ held that systems under which a town mayor, serving as judge, assessed fines that were paid into the town treasury violated the due process clause. A third case, In re Murchison, ${ }^{54}$ recognized that allowing a judge to assume an executive role can also endanger due process. The Court declared unconstitutional a Michigan procedure that allowed a judge to decide contempt charges he himself had brought on the grounds that the judge was serving in "his own case" by, in effect, assuming prosecutorial and judicial roles. ${ }^{.5}$

The Gourt never discussed the separation of powers implications of these decisions. Nor did it ever take the logical step of expanding these "two-hat" cases to situations in which one branch controls both executive and judicial functions. And, of course, it never recognized that the two-hat cases are an exception to the Dreyer doctrine. These cases do, however,

50. City of Rome v. United States, 446 U.S. 156, 179 (1980); see also cases discussed supra note 31; Burch v. Louisiana, 441 U.S. 130 (1979) (provision of Louisiana constitution allowing conviction by non-unanimous jury violates due process); Chapman v. Meier, 420 U.S. 1 (1975) (North Dakota constitution contained impermissible provisions for allocating seats in legislature); Duncan v. Louisiana, 391 U.S. 145 (1968) (provision of Louisiana constitution requiring jury trial only in some criminal cases violates due process); Reynolds v. Sims, 377 U.S. 533 (1964) (Alabama Constitution's sys$\mathrm{tem}$ of allocating seats in state legislature violates equal protection clause).

51. See R. BERGER, supra note 6, at 22-26 (Fourteenth Amendment passed to make Civil Rights Act of 1866's intervention in state voting procedures constitutional); Bonfield, The Guarantee Clause of Article IV, Section 4: A Study in Constitutional Desuetude, 46 MINN. L. REv. 513, 546 (1962) (Fourteenth Amendment introduced to add to Congress' power over states under the Guarantee Clause).

52. 273 U.S. 510 (1927) (due process bans mayor from judging suits because of mayor's "partisan" interest in filling town treasury and because portion of fines were added to mayor's salary); see also Dugan v. Ohio, 277 U.S. 61 (1928) (mayor holding virtually no executive power lacks partisan interest in suit and so can serve as judge).

53. 409 U.S. 57 (1972) (due process bans mayor from judging traffic violation suits because of mayor's partisan interest in fining defendants to fill town treasury); see also Gerstein v. Pugh, 420 U.S. 103, 125 (1975) (judicial officer must carry out probable cause hearing); Coolidge v. New Hampshire, 403 U.S. 443 (1971) (state attorney general cannot issue search warrants).

54. 349 U.S. 133 (1955).

55. Id. at 136; see also Figueroa Ruiz v. Delgado, 359 F.2d 718 (1st Cir. 1966) (judge interrogating witnesses in absence of prosecuting attorney violates due process); United States v. James, $440 \mathrm{~F}$. Supp. 1137 (D. Md. 1977) (judge presenting government case in traffic violation suit violates due process); Wounded Knee v. Andera, 416 F. Supp. 1236 (D.S.D. 1976) (Sioux tribal court in which judge serves as prosecutor violates due process); Haley v. Troy, 338 F. Supp. 794, 804 (D. Mass. 1972) (judge hearing cases of plaintiffs whom he coerced into filing suit violates due process). 
demonstrate that state government structure is not inherently insulated from federal due process scrutiny.

It might be argued that the level of federal intervention proposed by this Note is so much greater in degree than that allowed in the two-hat cases that federalism bars it as different in kind. Under the Warren and Burger courts' interpretations of the due process clause, however, federal courts have intervened as intrusively in regulating how states administer criminal justice as anything proposed here. ${ }^{58}$ Currently, for example, due process not only requires states to provide jury trials in criminal cases, ${ }^{57}$ but also determines how few jurors there may be ${ }^{58}$ and how they should be chosen. ${ }^{59}$ It demands that states provide lawyers to indigents, ${ }^{60}$ law libraries to prisoners, ${ }^{61}$ judicial probable-cause hearings to detainees, ${ }^{62}$ and Miranda warnings to subjects of "custodial interrogation." name of due process the Court has established standards states must follow when carrying out police searches ${ }^{84}$ or pre-trial identifications, ${ }^{65}$ issuing search warrants, ${ }^{68}$ and imposing the death penalty. ${ }^{67}$ Furthermore,

56. For evidence that the Burger court has maintained the Warren court's willingness to restructure state governments, see cases cited infra notes 56-69; see also Salzburg, Foreword: The Flow and Ebb of Constitutional Criminal Procedure in the Warren and Burger Courts, 69 Gro L.J. 151 (1980) (Burger Court has, overall, affirmed Warren court's tendency to impose defendant-protecting procedures upon state and federal law enforcement agencies).

57. See Muniz v. Hoffman, 422 U.S. 454, 477 (1975) (due process demands state provide jury trial for "serious" crime); Codispoti v. Pennsylvania, 418 U.S. 506 (1974) (due process demands state provide jury trial for crime punishable by over six-month imprisonment); Baldwin v. New York, 399 U.S. 66 (1970) (same); Duncan v. Louisiana, 391 U.S. 145 (1968) (due process demands state provide jury țial in criminal cases).

58. See Burch v. Louisiana, 441 U.S. 130 (1979) (state conviction by non-unanimous six-person jury violates due process); Ballew v. Georgia, 435 U.S. 223 (1978) (state conviction by jury of less than six people violates due process).

59. See Duren v. Missouri, 439 U.S. 357 (1979) (due process requires that state choose jurors from representative cross-section of community); Taylor v. Louisiana, 419 U.S. 522 (1975) (same); Ham v. South Carolina, 409 U.S. 524 (1973) (requiring state judge to ask voir dire questions on racial prejudice).

60. See Gideon v. Wainwright, 372 U.S. 335 (1963) (due process requires state to provide counsel to indigents); see also Baldasar v. Illinois, 446 U.S. 222 (1980) (state cannot use uncounseled misdeamenor conviction to elevate subsequent conviction to felony); Scott v. Illinois, 440 U.S. 367 (1979) (state must provide counsel in any suit leading to imprisonment); Argersinger v. Hamlin, 407 U.S. 25 (1972) (same); Gagnon v. Scarpelli, 411 U.S. 778 (1973) (state must provide counsel at sentencing hearing); Mempa v. Rhay, 389 U.S. 128 (1967) (same).

61. See Bounds v. Smith, 430 U.S. 817 (1977).

62. See Gerstein v. Pugh, 420 U.S. 103 (1975); see also Dunaway v. New York, 442 U.S. 200 (1979) (state must provide probable cause hearing whether or not state defines detention at issue as arrest).

63. Miranda v. Arizona, 384 U.S. 436 (1966); see also Edwards v. Arizona, 451 U.S. 477 (1981) (presumption against admission of statement made after defendant requested attorney); Estelle v. Smith, 451 U.S. 454 (1981) (banning use of state pretrial psychiatric examination obtained without Miranda warnings in sentencing hearing); Tague v. Louisiana, 444 U.S. 469 (1980) (per curiam) (state may not presume defendant knowingly waived Miranda rights).

64. See Taylor v. Alabama, 457 U.S. 687 (1982); Reid v. Georgia, 448 U.S. 438 (1980).

65. See Stovall v. Denno, 388 U.S. 293 (1967).

66. See Illinois v. Gates, 462 U.S. 213 (1983).

67. See Lockett v. Ohio, 438 U.S. 586, 604-05 (1978) (Ohio death penalty statute violates due 
once a provision of the bill of rights is found to be fundamental to the American scheme of justice, it is applied to the states exactly as it is enforced against the federal government. ${ }^{68}$ The Court has rejected any suggestion that federalism waters down the procedural safeguards that the incorporated provision imposes on the states. ${ }^{69}$

Federalism does, however, place some limits on how federal courts can enforce federal rights. Since the Supreme Court lacks supervisory power over the state courts, it can only impose constitutionally-dictated rules on the states. ${ }^{70}$ Accordingly, state constitutional provisions are deemed violative of the federal constitution only to the extent necessary to protect federal constitutional rights; the method of federal intrusion should be as

process by excluding individualized consideration of defendant's character and record); Coker v. Georgia, 433 U.S. 584 (1977) (death penalty for rape violates due process); Roberts v. Louisiana, 428 U.S. 325 (1976) (mandatory death penalty for first-degree murder violates due process); Proffitt v. Florida, 428 U.S. 242 (1976) (state capital sentencing procedure requiring jury to weigh variety of aggravating and mitigating circumstances upheld); Jurek v. Texas, 428 U.S. 262 (1976) (same).

68. See Gerstein v. Pugh, 420 U.S. 103, 111-13 (1975) (applying standards for federal probable cause hearings to states); Illinois v. Somerville, 410 U.S. 458 (1973) (applying federal double jeopardy standards to states); Benton v. Maryland, 395 U.S. 784 (1969) (same); Barker v. Wingo, 407 U.S. 514 (1972) (applying federal right to speedy trial to states); Vale v. Louisiana, 399 U.S. 30 (1970) (applying federal standards for unreasonable search and seizure to states); Chimel v. California, 395 U.S. 752 (1969) (same); Ker v. California, 374 U.S. 23 (1963) (same); Griffen v. California, 380 U.S. 609 (1965) (applying federal self-incrimination standards to states); Malloy v. Hogan, 378 U.S. 1 (1964) (same); Pointer v. Texas, 380 U.S. 400 (1965) (applying federal standards of the right to confront adverse witnesses to states).

69. See Y. Kamisar, W. Lafave \& J. Israel, Modern Griminal Procedure 30 (5th ed. 1980); Israel, Criminal Procedure, The Burger Court and the Legacy of the Warren Court, 75 Mich. L. Rev. 1320, 1327, 1330-31 (1977); Nowak, Due Process Methodology in the Post Incorporation World, 70 J. CRIM. L. \& CRImINology, 397, 398-400 (1979); Wilkes, The New Federalism in Criminal Procedure: State Court Evasion of the Burger Court, 62 Ky. L.J. 421, 424 (1974) (selective incorporation doctrine still unchallenged by Burger Court). Justice Harlan repeatedly advanced the argument that federalism requires that the Constitution impose a lesser standard of protection of incorporated rights on states than that imposed on the federal government, see Williams $v$. Florida, 399 U.S. 78, 117-38 (1970) (Harlan, J., concurring and dissenting in part); Griffen v. California, 380 U.S. 609, 615-17 (1965) (Harlan, J., concurring), but it was never accepted by the Court. Apadoca v. Oregon, 406 U.S. 404 (1972) (unanimous jury verdict not constitutionally mandated) is not contra. Eight justices agreed that the federal standard should apply to the states, but disagreed on what that standard was. Nor is Scott v. Illinois, 440 U.S. 367, 372-74 (1979) (since states regulate broader range of human conduct than does federal government, practicality, not federalism, may justify less stringent application of the right to counsel to certain state prosecutions than that applied to federal prosecutions). To the extent the Burger Court has limited Warren Court decisions, it has loosened controls on federal and state criminal enforcement equally. See Illinois v. Andreas, 463 U.S. 765 (1983) (weakening search and seizure standard but assuming application of federal standards to states); Washington v. Chrisman, 455 U.S. 1 (1982) (same); New York v. Belton, 453 U.S. 454 (1981) (same); Payton v. New York, 445 U.S. 573 (1980) (same); Oregon v. Mathiason, 429 U.S. 492 (1977) (per curiam) (narrowing Miranda requirements but assuming requirements apply equally to federal and state governments); Michigan v. Mosely, 423 U.S. 96 (1975) (same); Michigan v. Tucker, 417 U.S. 433 (1974) (same); Harris v. New York, 401 U.S. 222 (1971) (same).

70. See Ristano v. Ross, 424 U.S. 589, 597 n.9 (1976) (although Constitution does not require voir dire on racism in all interracial cases, Court would require it in federal courts); Barker v. Wingo, 407 U.S. 514, 523 (1972) (Court can only impose constitutionally-mandated rules on states); McNabb v. United States, 318 U.S. 332, 340-41 (1943) (Court's supervisory authority over federal criminal procedure exceeds its control over state procedure). 
unobtrusive as possible. ${ }^{71}$ The Court, in restructuring state governments under the due process clause has, therefore, only occasionally imposed a per se rule ${ }^{72}$ or a specific procedure upon the states. ${ }^{73}$ In most cases, it has defined a broad standard the states must meet, and allowed the states to devise procedures to meet that standard. ${ }^{74}$ In revising the Dreyer doctrine to allow federal courts to condemn specific allocations of executive and judicial powers, the Court would be creating such a broad standard. It would not demand federal court supervision of the daily functioning of state criminal procedures; it would only require that states devise new ways of distributing their powers. States would continue to prosecute, convict and punish criminals. To paraphrase the Court's observation last year, the proposed federal action requires states to accomplish their functions in a more careful manner than would otherwise be the case, but it does not require them to abandon those functions. ${ }^{75}$

\section{Due Process Scrutiny of Separation of Executive and Judicial Powers In State Government}

Because federalism limits, but does not bar, due process scrutiny of state separation of powers schemes, Dreyer should be replaced by an approach that safeguards the right to an impartial judge, yet respects state sover-

71. Reynolds v. Sims, 377 U.S. 533, 584 (1964). Cf. O'Shea v. Littleton, 414 U.S. 488, 502 (1974) (denying injunctive relief to plaintiffs who alleged they might be subjected to discriminatory enforcement of law by state judge); Rizzo v. Goode, 423 U.S. 362, 378-80 (1976) (denying injunctive restructuring of Philadelphia police department); Los Angeles v. Lyons, 461 U.S. 95 (1983) (denying injunction against use of chokeholds by Los Angeles police department). It must be emphasized that these cases turn on limitations of federal equity jurisdiction. See O'Shea, 414 U.S. at 499-500; Rizzo, 423 U.S. at 372-380; Lyons, 461 U.S. at 101. While holding that federalism constrained that jurisdiction, they also emphasized that alternate federal remedies limited the official action at issue. See O'Shea, 414 U.S. at 503-504; Lyons, 461 U.S. at 111-12.

72. See, e.g., North Carolina v. Pearce, 395 U.S. 711 (1969) (per se rule against increase of defendant's sentence after appeal and reconviction unless judge justifies increase with reasons relating to objective conduct of defendant); United States v. Wade, 388 U.S. 218 (1967) (per se exclusion of evidence from past indictment lineup at which defendant lacked counsel); Gideon v. Wainwright, 372 U.S. 335 (1963) (per se rule against conviction of indigent defendant lacking counsel); Mapp v. Ohio, 367 U.S. 643 (1961) (per se exclusion of evidence procured by illegal search).

73. See, e.g., California v. Prysock, 453 U.S. 355 (1981) (per curiam) (Miranda warnings not required if "fully effective" equivalent is given); Michigan v. Tucker, 417 U.S. 433 (1974) (Miranda warnings are prophylactic standards designed to safeguard due process rights).

74. See Illinois v. Gates, 462 U.S. 213, 230 (1983) (magistrate must look to "totality of circumstances" when deciding whether to issue search warrant); Gerstein v. Pugh, 420 U.S. 103, 125 (1975) (states must provide "fair and reliable determination of probable cause [by judicial officer] as a condition for any significant pretrial restraint of liberty"); Stovall v. Denno, 388 U.S. 293, 301-02 (1967) (state identification procedures may not be "unnecessarily suggestive and conducive to irreparable mistaken identification"); Neil v. Biggers, 409 U.S. 188, 196 (1972) (same); Barker v. Wingo, 407 U.S. 514 (1972) (states must provide speedy trial, but courts will look to length of delay, reason for delay, defendant's assertion of his right and prejudice to defendant in determining whether that right has been denied).

75. E.E.O.C. v. Wyoming, 460 U.S. 226, 239 (1983) (holding that federalism does not bar Congress from applying age-discrimination legislation to state government). 
eignty. This section proposes such an approach and illustrates how it might be applied.

\section{A. The Proposal}

Separation of powers doctrine identifies several interrelated characteristics of a state system that adequately separates executive and judicial powers. The system will economize on virtue by relying on fair procedures, rather than on honest office holders, to ensure that the executive lacks the ability unduly to influence the judiciary. ${ }^{76}$

The analysis in the "two-hat" cases explains what constitutes "undue influence." In Tumey $v$. Ohio ${ }^{77}$ the Court first stated that "[e]very procedure which would offer a possible temptation to the average man as a judge. . .not to hold the balance nice, clear and true between the State and the accused, denies the latter due process of law, ${ }^{\prime 78}$ then forcefully observed that "[a] situation in which an official perforce occupies two practically and seriously inconsistent positions, one partisan and the other judicial, necessarily involves a lack of due process of law in the trial of defendants charged with crimes before him."79

Separation of powers doctrine suggests the court must look to a complex set of factors to determine whether a specific state structure generates undue influence under the two-hat analysis. At the outset, the court must examine the nature of the interrelationship of the executive and judicial branches. The entwining of the two may simply realize the goal of separation of powers doctrine, that each branch have the means of checking the other. On the other hand, the interlock may be so tight that the judge is no longer an outsider impartially observing the executive's case, but has absorbed the executive's interest in conviction. The interlock may also pose due process dangers by granting the executive so much power over the judiciary that the executive can dictate or influence the judge's decision.

Second, the court must determine whether these shortcomings are serious enough to violate due process. In determining whether the state structure tempts the average person as judge sufficiently to render the balance between state and defense no longer "nice, clear and true," the court must

76. See supra notes $16-18$ and accompanying text.

77. 273 U.S. 510 (1927).

78. Id. at 532 .

79. Id. at 534. The average-person standard does not conflict with situations in which judges are assumed to have more than the average person's ability to remain objective, such as after disallowing prejudicial evidence, or after guilty pleas have been withdrawn. In such cases, the judge is under no direct institutional pressure to decide the case on the executive's behalf. Furthermore, in some cases objectivity can be learned. The judge, for example, can remain objective after disallowing prejudicial evidence because he has learned to recognize the non-probative value of such evidence. 
determine whether the relationship between the branches is likely to bias the judge in actual cases. ${ }^{80}$ This requires that the branch of the executive influencing the judge have a partisan interest in the outcome of the trial. Just as in other due process inquiries, however, the Court does not need to find actual bias in any specific case. The determination that a particular procedure creates a possibility of bias would be sufficient to establish its unconstitutionality.

Admittedly, due process scrutiny of state separation of executive and judicial powers may require a difficult weighing of competing factors. But it requires no more weighing than most other due process inquiries and certainly no more than the "two-hat" analysis already applied in Tumey, Ward and Murchison. ${ }^{81}$ Although the boundaries of constitutionally permissible state structures are broad, they are not limitless. Courts must police those limits.

\section{B. The Standard Applied}

The most significant advantage of overruling Dreyer is that potentially dangerous state systems, perhaps as yet undeveloped, can be subjected to due process scrutiny. The result in Dreyer, however, would not change. Though the Illinois State Board of Pardons was technically an executive body that decided whether a prisoner should be released, ${ }^{82}$ it had no partisan interest in the outcome of the hearing, nor was it alleged to be subject to influence from any individual who $\operatorname{did}^{83}$ Other state structures, how-

80. The test to determine when inadequate separation of powers poses due process problems in administrative agencies, see Withrow v. Larkin, 421 U.S. 35, 47 (1975) (court should assume honesty of those serving as adjudicators and require defendant to prove absence of separation of powers poses due process problems), should not be applied to separation of powers in state criminal procedures for four reasons. First, the courts have not applied the Withrow standard outside of the administrative context, see Hortonville Joint School District No. 1 v. Hortonville Educ. Ass'n, 426 U.S. 482, 491 (1976). Second, liberty rights at stake in criminal proceedings merit higher due process protection than rights at stake in administrative cases. See supra note 12. Third, administrative agency cases involve a combination of investigative and adjudicative functions, not a linking of partisan and judicial roles. See Hortonville, 426 U.S. 482 (school board investigates and punishes striking teachers); Withrow, 421 U.S. 35 (examining board of physicians investigates and can revoke licence of physician); Wolff v. McDonnell, 418 U.S. 539 (1974) (prison disciplinary committee investigates and punishes prisoner misbehavior); Arnett v. Kennedy, 416 U.S. 134 (1974) (regional office of Office of Economic Opportunity investigates and institutes removal of federal employee); Fourth, availability of de novo judicial review of administrative decisions lowers the due process standard applicable to administrative agencies. See Ingraham v. Wright, 430 U.S. 651, 679-80 (1977) (subsequent judicial remedy sufficient to safeguard rights of child punished in schools).

81. See supra notes $52-55$ and accompanying test.

82. 187 U.S. 71, 79-83 (1902).

83. Similar argument reinforces the court's holding in Bean v. Nevada, 410 F. Supp. 963 (D.C. Nev. 1974) (state board of pardons made up of executive and judicial branches not subject to due process challenge as violating separation of powers). The board was not alleged to have a "partisan" interest in the outcome of its adjudication. Furthermore, in Bean, executive control over the decision was tempered by judicial presence on the board. 
ever, which have been protected by the Dreyer doctrine would fare less well. $^{\text {s4 }}$

\section{Executive Power Over the Judiciary}

Systems of executive selection and removal of judges potentially raise serious problems, ${ }^{85}$ but most states that place the selection and removal powers in executive hands structure the procedure so as to reduce the executive's ability to influence or control the judiciary ${ }^{86}$ Most such states require the legislature or an elected "governor's council" to approve the judges nominated by the governor. ${ }^{87}$ Furthermore, the judges' lengthy

84. The Arkansas statute upheld in Pollard v. Roberts, 283 F. Supp. 248 (E.D. Ark.) aff d, per curiam, 393 U.S. 14 (1969), which conferred subpoena power upon prosecuting attorneys, would fail the test. The attorney would naturally be prone to make a biased decision as to whether a given document was relevant to his investigation. The California Penal Code provision requiring approval by the prosecuting attorney before judge can grant probation, upheld in Chromiak v. Fields, 406 F.2d 502 (9th Cir. 1969), cert. denied, 396 U.S. 1017 (1970), has been repealed by the California legislature, see Cal. Penal Code $\S 1203$ (West 1982). It would probably also fail under the proposed standard. The executive interest in sentencing is not as pronounced as the executive interest in conviction. Nonetheless, the executive's adversarial relationship with the defendant might bias the attorney toward demanding strict sentences for convicted defendants. Similarly, the Nebraska statute upheld in Martin v. Parratt, 412 F. Supp. 544, 549 (D.C. Neb. 1976) (Nebraska habitual criminal statute allowing prosecutors to seek mandatory enhanced sentences for habitual criminals) would survive only if it left prosecutors minimal discretion to decide whether to bring the fact that the criminal was a habitual offender to the attention of the judge. Under the Nebraska law, once the judge knew the defendant was a habitual offender, the sentence was mandatory.

85. See The Federalist No. 78, (A. Hamilton) (greatest threat to separation of powers posed when one branch has power to appoint and remove members of another branch).

A test analogous to the one proposed here would not invalidate state systems of elected judiciaries, though such an outcome would satisfy many scholars who argue that elected judiciaries pose due process problems. See A. Sturm, Thirty Years of State Constrtution-Making: 1938-68 (1970); Elliot, Essential Elements of a Model Judiciary Article, in INSTITUTE OF JUDICIAL ADMINISTRATION: Selected Special Studies (1959). Elected judiciaries should be distinguished from fusions of executive and judicial powers on several grounds. First, the electorate does not hold a "partisan" interest in convicting a particular defendant. If the electorate were essentially deciding a case by referendum, or if the judge ran on a platform of convicting a particular defendant, most agree that due process problems would arise. See L. Tribe, American Constrtutional Law, $494-95$ (1978). Second, most systems of elected judiciaries have extensive safeguards to prevent popular pressures biasing the judge. The Missouri system, adopted by the majority of states with elected judiciaries, requires nomination of a list of candidates for judges' positions by a legislative committee, a selection of the nominee by the governor, and confirmation by the people. See A. STURM, Modernizing State Constiturions (1973). Third, the people are the source of power in state constitutions. Their decision to directly elect their officers carries much weight. It is far less likely that the people are aware of the specific intermingling of executive and judicial powers developed by their state governments. Fourth, long usage supports elected judiciaries. Most state governments, on the other hand, do not entwine the executive and judicial powers so as to endanger the due process right to an impartial tribunal. The institutional pressures against changing the system of elected judiciaries are, therefore, far more pronounced than the pressures supporting judicial and executive merger. See Love, The Election of Judges by the People for Short Terms of Office, in LAW AND AMERICAN HisTORY, supra note 48, at 437; see also Burch v. Louisiana, 441 U.S. 130, 138 (1979) (uniform judgment of nation as expressed through state procedures provides useful guide to what practices are constitutionally permissible).

86. Connecticut, Delaware, Hawaii, Maine, Massachusetts, New Hampshire, New Jersey, and New York have some form of executive appointment of judges. See infra notes 87-89.

87. ConN. CoNST. art. V., $\$ 2$ (governor appoints judges with approval of general assembly); 
terms $^{88}$ and the requirement that the legislature initiate judicial impeachment proceedings ${ }^{89}$ further reduce executive influence.

New York, however, creates a system of executive appointment of judges, which, though it has been upheld in reliance on Dreyer, ${ }^{90}$ raises serious due process problems. The New York Constitution allows the Governor to select the judge to hear a specific case at a specific time. ${ }^{91}$ The Governor's decision to hold the Extraordinary Term, his selection of the case to be heard, and of the judge to hear it, are not reviewable. ${ }^{92}$

Executive selection of judges for specific cases bypasses the safeguards against bias, such as legislative oversight of the Governor's decision and lengthy judicial terms, found in other state systems. The Governor has the ability to influence the outcome of the case by selecting a judge who will handle it the way the Governor wishes. The fact that the Governor selected a specific case for adjudication suggests he may hold a partisan interest in the outcome. Indeed, the cases decided by Extraordinary Terms in New York have been sensational murders, ${ }^{93}$ investigations into official corruption, ${ }^{94}$ or similar cases in which the state has a peculiar interest over and above its ordinary concern in criminal cases. Allegations of judicial bias in cases heard in Extraordinary Terms are common. ${ }^{95}$ Even if

DEL. CoNST. art. IV $\S 3$ (governor appoints with advice and approval of senate); HAWAII CoNST. art. V, $\S 3$ (same); N.J. CoNST. art. VI, $\S 6$, cl. I (same); ME. ConsT. art. V, pt. $1, \S 8$ (judicial officers nominated and appointed by Governor with advice and consent of governor's council); N.H. Const. pt. II, art. 46 (same); MASs. ConST. pt. 2, ch. II, $\$ 1$, art. 9 (same).

88. CoNN. Const. art. V, $\$ 2$ (eight-year term for superior and circuit courts); DEL. ConsT. art. IV, $\S 3$ (twelve-year terms); HawaII CoNST. art. V, $\S 3$ (ten-year terms); ME. CoNST. art. VI, $\S 4$ (seven-year terms); MASs. CoNST. pt. 2, ch. III, art. I (good behavior); N.H. CoNST. pt. II, art. 73 (good behavior); N.J. CoNST. art. VI, $\S 6$, cl. 3 (seven-year terms for supreme and superior court judges, extended to good behavior after reappointment).

89. ConN. Const. art. V, § 2 (judge impeached by legislature); DEL. ConST. art. III, $\S 12$ (same); Me. Const. art. VI, $\S 4$ (same); N.J. ConsT. art. VI, § 6, ๆ4 (same); HawaII Const. art. $\mathrm{V}, \S 4$ (board established by legislature recommends removal to executive who appoints second board to investigate; if second board recommends dismissal, executive dismisses judge); N.H. CoNsT. pt. II, art. 73 (removal by Governor with consent of Council upon address of both houses, except in case of advanced age or mental or physical incompetence, in which case governor may remove judge on his own authority; no record of this potentially dangerous power being abused); MASS. CoNST. pt. II, ch. III, art. 1 (same).

90. See People v. Davis, 67 Misc. 2d 14, 16, 322 N.Y.S. 2d 927, 930 (S. Ct., Ontario Co. 1971).

91. N.Y. ConsT. art. VI, § 27.

92. Cunningham v. Nadjari, 39 N.Y.2d 314, 347 N.E.2d 915, 383 N.Y.S.2d 590 (1976); People ex rel. Saranac Land and Timber v. Extraordinary Term, 220 N.Y. 487, 116 N.E. 384 (1917).

93. People v. Gillette, 191 N.Y. 107, 83 N.E. 680 (1908) (nephew of factory owner seduces uncle's employee, refuses to marry her, clubs her to death with tennis racquet while on boating trip); People v. Shea, 147 N.Y. 78, 41 N.E. 505 (1895) (defendant and group of political allies murder pollwatcher who tried to stop them from voting illegally). Gillette was the basis for T. DREISER, AN American Tragedy (1925).

94. See United States ex rel. Monty v. McQuillan, 385 F. Supp. 1308 (E.D.N.Y. 1974); Dondi v. Jones, 40 N.Y.2d 8, 351 N.E.2d 650, 386 N.Y.S.2d 4 (1976); People v. INeff, 191 N.Y. 167, 83 N.E. 970 (1908)(investigations of corruption by state officials); cf. People ex rel. Saranac Land and Timber v. Extraordinary Term, 220 N.Y. 487, 116 N.E. 384 (1917) (Extraordinary Term called after plaintiff won three suits against state for state lands).

95. See Pitler, Superseding the District Attorneys in New York City-The Constitutionality and 
the allegations are unfounded, they suggest that the system creates the possibility and appearance of bias. This appearance of bias, together with the risk that inadequate separation of executive and judicial powers will allow the Governor, holding a partisan interest in the outcome of the suit, to exercise sufficient control over the judiciary to bias a judge, suggests that the Term violates due process. ${ }^{98}$

\section{Judicial Control Over the Executive}

Judicial involvement in the prosecution of a case can also give a judge a partisan role in a criminal suit. Connecticut's recently reformed system of states' attorneys was a case in point, which, under the Dreyer doctrine, was shielded from due process scrutiny ${ }^{97}$

Until 1984 the Chief Justice of the Connecticut Supreme Court appointed the Chief State's Attorney. ${ }^{88}$ The judges of the superior court ap-

Legality of Executive Order No. 55, 41 FordHAM L. REv. 517, 544 n.162 (1972) (judicial bias apparent in Extraordinary Term handling of investigation into corruption in N.Y. City police department); Cunningham v. Nadjari, 39 N.Y.2d 314, 347 N.E.2d 915, 383 N.Y.S. 2d 590 (1976) (plaintiff's contention that Extraordinary Term was granting subpoenas to harass defendant and manipulate public events and media plausible).

96. New York and federal courts have upheld the New York system. See People ex. rel. Saranac Lake Land and Timber v. Extraordinary Term, 220 N.Y. 487, 116 N.E. 384, 385 (1917) (Extraordinary Term necessary because Governor might need to call session for reasons of public welfare which courts could not know); United States ex rel. Monty v. McQuillan, 385 F. Supp. 1308 (E.D.N.Y. 1974) (upholding Term on ground that defendant does not have due process right to randomly selected judge, but not discussing pressures toward bias in New York system); $c f$. Mulroy v. Carey, 58 A.D.2d 207, 396 N.Y.S.2d 928 (1977) (Extraordinary Term does not create risk of unconstitutional influence over the prosecution), aff'd, 43 N.Y.2d 819, 373 N.E.2d 369, 402 N.Y.S.2d 570 (1977).

97. Connecticut courts have upheld the statute in the face of separation of powers and due process challenges. State v. Moynahan, 164 Conn. 560, 569-70, 325 A.2d 199, 206-07 (1973), cert. denied, 419 U.S. 976 (1974), asserted that the system functioned effectively for 270 years with no prejudice to those accused of criminal offenses, $i d$. at $570,325 \mathrm{~A} .2 \mathrm{~d}$ at 207 , and found no violation of Connecticut Constitution art. II (requiring separation of powers in state government) because state's attorneys are officers of the court, whose role is to see that impartial justice is done, id. at $569,325 \mathrm{~A} .2 \mathrm{~d}$ at 206. Neither of the Court's arguments is persuasive. First, its assertion that the accused have not been prejudiced by the Connecticut system is belied by studies of the system. See Citizens Crime Commission of Connecticut, Report on the Prosecutorial Function 4-5 (1984) (Connecticut judges biased by system of selecting prosecutors); Newman, Prosecutor and Defender Reform: Reorganization to Increase Effectiveness, 44 CoNN. B. J. 567, 569 (1970) (Connecticut judges determine how cases will be pleaded over better judgment of prosecutors and defense). Second, in an adversarial system the prosecutors, though technically officers of the court, have an overriding interest in convicting defendants. See supra note 12. Furthermore, the issue is whether the judge is biased by being too closely tied to the prosecuting function, so the status of prosecutors as "officers of the court" begs the question. See also Moynahan v. Manson, 419 F. Supp. 1139 (D. Conn. 1976), aff'd 559 F.2d 1204 (2d. Cir. 1977); Connecticut v. DiLeo, 28 Conn. Supp. 354, 261 A.2d 547 (1969) (relying on Moynahan to uphold Connecticut system); cf. United States v. Richmond, 277 F.2d 702 (2d Cir. 1960) (no due process violation arises when the judge selects public defenders). The Richmond situation is not analogous to judicial selection of prosecutors because: (a) the due process requirement that defendants receive a fair trial suggests that judicial bias in favor of a criminal defendant is less serious than bias against a defendant; and (b) judicial selection of a defender implements a constitutional right to counsel. No constitutional right is involved in judicial selection of a prosecutor.

98. Conn. Gen. Stat. AnN. \& 51-278 (b) (1) (West Supp. 1982). In November 1984, Connecticut amended its constitution to provide that a Criminal Justice Commission, selected by the Governor 
pointed the state's attorneys for their judicial districts, ${ }^{99}$ determining how many assistants the states' attorneys needed, appointing deputy and assistant states attorneys to fill that need, ${ }^{100}$ setting the deputies, and assistants' salaries, reappointing the attorneys after their four year terms, ${ }^{101}$ and, through a committee of Superior Court judges, removing the attorneys from office when necessary. ${ }^{102}$

The opportunity for judges in this system to become too closely involved in the prosecution is obvious. The extent to which judges actually did so was a subject of much debate in Connecticut. ${ }^{103}$ It has been suggested that under the Connecticut system the judge in effect decided what cases would be brought and how they would be pleaded. ${ }^{104}$ To the extent this was true, the judges had become intimately involved in the prosecution's case. Such intimate involvement creates the possibility that the judge would no longer be able to view that case with an impartial, detached eye. It thereby violated due process.

\section{CoNCLUSION}

This Note provides a way to subject dangerous state systems such as New York's Extraordinary Term and Connecticut's judicial appointment of prosecutors to due process scrutiny. Courts should not dismiss difficult due process problems posed by inadequate separation of judicial and executive powers in state government with short, uncritical references to Dreyer. Separation of powers principles flow naturally into the current of modern due process analysis. The Supreme Court should allow their merger by providing for due process review of state separation of executive and judicial functions in criminal prosecutions.

-David A. Martland

and confirmed by the legislature, would select State's Attorneys. Three Changes Supported by Voters, HARTFORd Courant, Nov. 7, 1984, at A20.

99. Id.

100. Id.

101. Id. § 51-278 (b)(2)(B)-(C).

102. Id. § 51-278 (b)(5).

103. See Cirtzens CrIme Commission, supra note 97, at 1 (consensus in Connecticut government that procedure for selecting states attorneys must be modified).

104. Newman, supra note 97, at 569; Crrizens CRIME Commission, supra note 97, at 4 (judge biased by Connecticut system). 